\title{
The Grammatical Error Analysis Found in Students' Composition
}

\author{
Tri Jampi Setiyorini ${ }^{1^{*}}$ \\ Puspa Dewi ${ }^{2}$ \\ Edi Sunjayanto Masykuri ${ }^{3}$ \\ Universitas Muhammadiyah Purworejo \\ K.H.A. Dahlan Road 3 \& 6 Purworejo, Central Java, Indonesia \\ *trijampi95@gmail.com
}

Article history: Submitted on $30^{\text {th }}$ October, 2020; Accepted on $15^{\text {th }}$ December 2020;

Published on 31 th December 2020

\begin{abstract}
Grammar is an important language component to enhance students' language proficiency. However, many students still make grammatical errors in writing their essays. This research aims at analyzing types of grammatical errors found in students' essays. The type of this research is a descriptive case study. The subjects of the study were 20 third-semester students of Purworejo Muhammadiyah University, Indonesia. The researchers used a test to collect the data. The results of tests were analyzed descriptively by using Keshavarz's theory. The analysis result shows that the percentage for each error type is $34.06 \%$ (omission), $7.25 \%$ (addition), $57.97 \%$ (substitution), and $0.72 \%$ (permutation). Based on the research result, the researchers conclude that the most dominant error is substitution. The percentage of error can prove it, that is, $57.97 \%$. There are some implications of error analysis in English language teaching in universities in Indonesia. The lecturer can give enrichment, understand students' grammar competence, give corrective feedback to students' errors, modify target language learning items in classrooms and textbooks, understand the way students apply the target language rules, and use the effective teaching method or learning media.
\end{abstract}

Keywords: error analysis, grammar, essay writing

\section{ABSTRAK}

Tata bahasa adalah sebuah komponen yang penting untuk meningkatkan kemampuan bahasa mahasiswa. Namun, banyak mahasiswa yang masih melakukan kesalahan tata bahasa dalam menulis esai. Penelitian ini bertujuan menganalisis kesalaban tata bahasa pada esai mahasiswa. Jenis penelitian ini adalah studi kasus deskriptif. Subjek penelitian ini adalah 20 mahasiswa semester 3 di Universitas Mubammadiyah Purworejo, Indonesia. 
Peneliti menggunakan tes untuk mengumpulkan data. Hasil tes dianalisis secara deskriptif dengan menggunakan teorinya Keshavar: Hasil analisis menunjukkan bahwa persentase kesalahan adalab 34.06\% untuk omisi, 7.25\% untuk adisi, 57.97\% untuke. substitusi, dan $0.72 \%$ untuk permutasi. Berdasarkan hasil penelitian, peneliti menyimpulkan bahwa jumlah kesalahan yang paling dominan adalah substitusi. Presentase kesalahan dapat membuktikannya yaitu 57.97\%. Ada beberapa implikasi analisis kesalahan terbadap pengajaran bahasa Inggris di universitas di Indonesia. Dosen dapat memberikan pengayaan, memahami kompetensi tata bahasa mahasiswa, memberikan umpan balik korektif untuk kesalahan mahasiswa, memodifikasi materi pembelajaran bahasa target di kelas dan di buku, mengetahui cara mahasiswa menerapkan peraturan bahasa target, dan menggunakan metode pengajaran atau media pembelajaran yang efektif.

Kata Kunci: analisis kesalahan, tata bahasa, penulisan esai

\section{INTRODUCTION}

Basically, being a professional teacher in English, students should have best mastery in four language skills: reading, writing, listening, and speaking. Those skills are integrated to make good communicative competence. The third-semester students in a university must learn how to compose an essay better. Some types of essay: chronological essay, cause and effect essay, comparison/contrast essay, and argumentative essay (Oshima \& Hogue, 1998). For every meeting of the lecture, students must learn and write one type of essay based on the lesson plan. Students must write sentences grammatically to produce an essay in a good composition. Grammar is a basic language component that needs attention and emphasis from EFL teaching practitioners (Calanoga, 2019). It is important because the students still meet some difficulties in using tenses and they do not recognize the language structure as well (Simbolon, 2015). Grammar enables learners to combine linguistic units in a grammatical sentence with its rules (Afdaleni, 2018; Patoc $\&$ Lasaten, 2019). Adequate grammar competence enables learners to make effective communication because they always apply grammatical accuracy in using the language (Marashi, 2014). By using grammar, students can explain their thoughts vividly and meaningfully (Bradshaw in Sioco \& Vera, 2018). If students do not have good grammar knowledge, they do not understand how to write sentences grammatically and how to comprehend their meaning (Cam \& Tran, 2017).

Although the third-semester students of Purworejo Muhammadiyah University, Indonesia, have studied English for a long time, they still find some problems in writing an essay because writing is a complex process of collecting ideas on their mind and changing them into a good text. Besides, they are unable to apply grammatical rules correctly. The students omit the inflection $-s /-e s$ to show the plurality of a noun. They still omit the inflection 
$-s$ to the verb to show the tense marker in the present simple when the subject is singular. The students also do not put the verb be (is, am, or are) to write a nominal sentence in the present simple. When the sentence contains a gerund, they also do not use the inflection -ing. They also sometimes miss the article in constructing a sentence. Besides, they also do not put a subject or an object in writing a sentence.

In some cases, the students still use a singular verb instead of a plural verb, and vice versa. They also use a plural noun instead of a singular noun. They sometimes attach double auxiliaries such as is and should in one sentence. They also use a present verb with an inflection $-s$ to write an affirmative sentence with a modal auxiliary can. Some of them also use the past verb after the phrase being able to instead of an infinitive verb. They also still use a progressive verb in constructing the subordinate clause for the first type of conditional sentence. Besides, they put an auxiliary verb or a preposition which is not necessary in a sentence.

In other cases, some students use an adjective instead of a noun; for example, bealthy instead of health. The students sometimes use a noun instead of a verb; for example, consumption instead of consume. They also use the incorrect pronoun instead of the correct one such as our instead of your. Some students sometimes misspell words such as healt and chage. Besides, they do not arrange sentences correctly. In these cases, students make errors, but they do not recognize them.

Errors occur when students frequently do not use the structure of language correctly (Dulay et al. in Calanoga \& Arellano - Tamayo, 2019). Students make errors frequently, but they do not know that those are errors (Gass \& Selinker in Catabay, 2019). Errors are the systematic deviations of grammatical items that show students' knowledge in the target language (Brown in Catabay, 2019). Errors occur when students lack competence in the target language, the errors appear frequently, but they do not know how to correct them (Ellis in Shariq, 2020). They are the results of what students have learned about the target language (Gass \& Selinker in Ramos, 2015). Errors show the way students learn a language, so teachers can set the goals of learning and improve their teaching methods (Mendoza, 2016). Errors can display students' target language ability and give signs about language teaching techniques, language teaching effectiveness, and evaluation techniques (Palmer in Hamilton, 2015). Thus, teaching practitioners need to conduct error analysis to understand the types of students' errors.

Error analysis examines what kinds of errors students make in second language learning (Hinkel in R et al., 2018). It enables teachers to identify, categorize, and describe learners' grammatical errors in a second language learning (Batu et al., 2018). It always applies linguistics theories and procedures in examining students' errors (Ruru \& Ruru in Oktaviana, 2018). Error analysis informs what students know and how they apply the knowledge of the target language (Corder in Manuel, 2019). Error analysis can also indicate the effectiveness of teaching materials and strategies, and 
teachers can modify the materials in the syllabus (Khansir, 2012). It helps teachers to detect students' difficulties in the target language learning and helps them to choose the effective method in teaching the target language (Heydari \& Bagheri, 2012).

Errors can be categorized based on their processes. They explain how students commit errors. There are four types of errors: omission, addition, substitution, and permutation (Keshavarz, 2012). Below is a detailed explanation of each error type.

1. Omission

The omission is the absence of necessary items within a sentence (Corder in Kusumawardhani, 2017). For example, *I am study bistory now instead of I am studying history now. Here, the inflection -ing must be added to the main verb study to indicate the present continuous tense.

2. Addition

The addition is the presence of an unnecessary particular item within a sentence or an utterance (Tizon in Rusyaidi, 2018). For example, *They are always play basketball at 10 a.m. instead of They always play basketball at 10 a.m. Here, the auxiliary verb are is not necessary because there is the main verb play, and the sentence is in the present simple.

3. Substitution

The substitution uses the incorrect form of a word in a sentence or an utterance (Keshavarz, 2012). For example, *Pragmatics is different to sociolinguistics instead of Pragmatics is different from sociolinguistics. Here, the correct preposition for the adjective different is from.

\section{Permutation}

The permutation is the placement of a morpheme or a word in a sentence or an utterance which is not arranged correctly (Keshavarz, 2012). For example, *He runs always in the yard instead of He always runs in the yard. In this sentence, the adverb of frequency always should be placed before the main verb runs.

In this research, the researchers analyze errors in students' composition. Composition means essay writing. Writing is a difficult language skill that enables students to convey their thoughts, knowledge, and feelings in a text that can be understood and read by many people (Pamittan, 2019; Talosa \& Maguddayao, 2018). Good grammar competence and adequate vocabulary are necessary to make all ideas readable in a well-structured text (Fontiveros - Malana \& Calanoga, 2019). Learners can convey their messages clearly in written form to make the readers understand the information (Ratnah, 2018). They have to use some linguistics elements of writing to enable readers to comprehend the text and involve motor and cognitive skills (Ilyas, 2019; Sidupa \& Rahyono, 2019). Learners having writing proficiency can master English effectively, improve their English performance, and attain high level achievement (Catabay, 2019; Susanto et al., 2019).

The researchers have done the study to identify the similarities and differences in their errors with the hope that it could help in the teaching and 
learning of English (Zheng \& Park, 2013). The study stated that by making a comparison between the two languages, most of the learners' errors could be predicted as considered as language interference (Siew Eng et al., 2020). Qamariah and Wahyuni (2020) have conducted error analysis using to be as an auxiliary and linking verb in students' writing text. The errors are classified by Dulay, Burt, and Krashen's theory. The result showed there are any misformation, omission, and misordering (Qamariah \& Wahyuni, 2020). Anjayani and Suprapto (2014) have analyzed the errors in using prepositions in students' writing made by the eleventh-grade students of a senior high school. The result of data analysis showed that there were 117 incorrect uses of prepositions, and the most dominant error was the use of the preposition of place. Inter-lingual transfer was the cause of students' errors. The teacher should apply the appropriate learning media to teach prepositions effectively. The government and the syllabus developer should include preposition materials to improve students' understanding about them (Anjayani \& Suprapto, 2016). Swasti (2016) has analyzed the errors in using English articles on students' descriptive texts. The result of this study shows that indefinite a/an-for-zero errors are $61.51 \%$, zero-for-indefinite a/an errors are $22.19 \%$, definite the-for-indefinite a/an substitution errors are $5 \%$, definite the-for-zero substitution errors are $4.65 \%$, zero-for-definite the substitution errors are $4.41 \%$, and indefinite a/an-for-definite the substitution errors are $2.23 \%$. The teacher should focus on students' errors and improve grammar teaching quality (Swasti, 2016).

The researchers have taken several previous studies about error analysis in three different cases. The first previous research has analyzed errors in using auxiliary verb (to be) and linking verbs, the second previous research has analyzed errors in using prepositions, and the last previous research has analyzed errors in using English articles. In this research, the researchers research error analysis of grammar found in college students' essays because the researchers have found many grammatical errors in the third-semester students' essays. This research focuses on analyzing types of grammatical errors found in students' essays written by 20 students in the third semester of Purworejo Muhammadiyah University, Indonesia. Here, the researchers analyze all kinds of grammatical errors found in students' essays to detect what students know about the target language. The researchers hope that English lecturers can identify students' difficulties in language learning, detect students' knowledge in the target language, provide feedback to minimize students' errors, modify the target language materials, and determine the appropriate method, learning media, or strategy to enhance students' language proficiency. The researchers analyze types of errors using Keshavarz's theory (2012). The analysis is based on the classification of the process. It is different from the previous research because the previous research analyzed errors using Dulay, Burt, and Krashen's theory. The researchers support the previous researches that the teaching practitioners ought to focus on students' errors, include the materials containing students' 
errors, and apply the effective teaching method, learning media, or strategy. When the teaching practitioners give more attention to students' errors and improve the teaching grammar quality, they will give positive effects on students' writing because grammar is a vital component in writing.

Based on the study's background that the researchers have stated before, the researchers formulate the research problems as follows:

1. What are the types of grammatical errors found in students' essay writing?

2. What is the most dominant type of grammatical error found in students' essay writing?

\section{METHOD}

In this research, the researchers used a descriptive case study. A descriptive case study aims to present detailed information on a specific phenomenon to get a deep understanding of the case (Heigham \& Croker, 2009). In this study, the researchers presented detailed information about grammatical errors found in the essay writing. The subjects of the study were 20 third-semester students of a Purworejo Muhammadiyah University, Indonesia. The data sources of this research were documents. The documents were in the form of essays written by 20 third-semester students of Purworejo Muhammadiyah University, Indonesia. The analysis unit is the sentences found in essays written by 20 students in the third semester of Purworejo Muhammadiyah University, Indonesia.

The researchers used a test to collect the data. A test can detect a person's ability in a given domain. In this study, the researchers collected the data by giving a test to 20 students. The test was writing an essay based on the topic they have chosen. Here, the researchers took some steps to collect the data.

\section{Graphic 1:}

The Steps of Collecting the Data

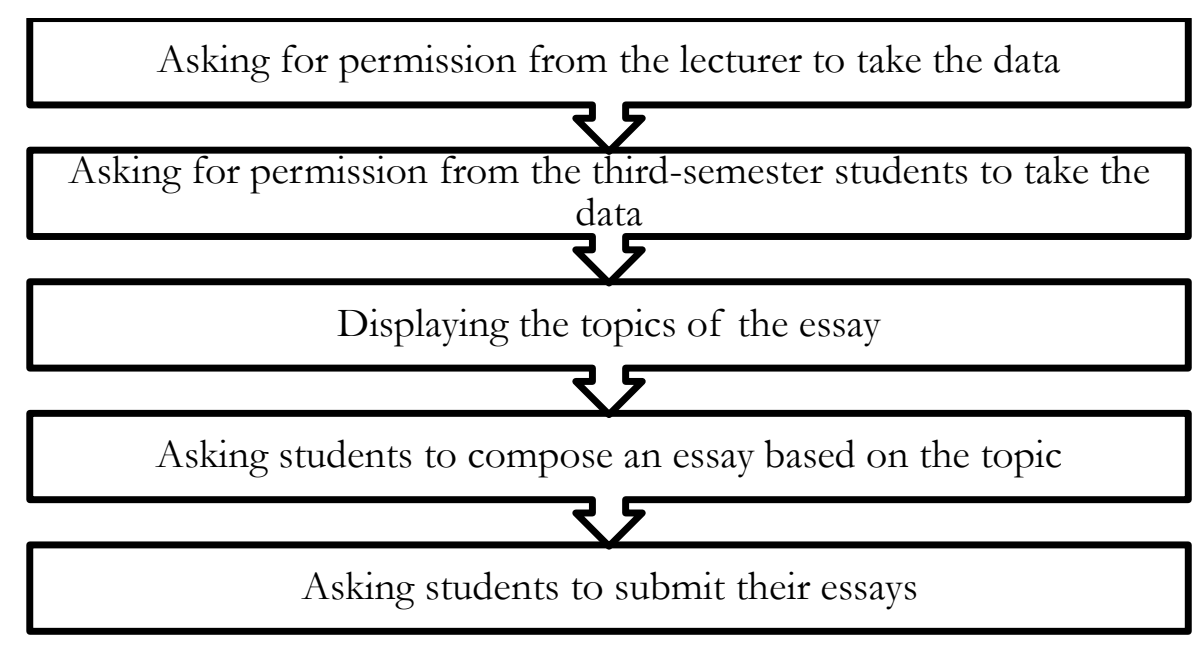


The researchers analyzed the data by using some steps as follows:

1. Reading the results of students' essays

2. Highlighting grammatical errors in students' essays

3. Categorizing grammatical errors found in students' essays

4. Giving explanations of the types of grammatical errors found in students' essays

5. Gathering and counting the result and putting it into the table

6. Calculating the percentage of each error found in students' essays

The researchers calculated the percentage of each error made by the thirdsemester students using the formula as follows:

$\mathrm{P}=\mathrm{f} / \mathrm{n} \times 100 \%$

Note:

$\mathrm{P}=$ percentage of the number of error

$\mathrm{f}=$ frequency of each type of error

$\mathrm{n}=$ number of error

7. Interpreting and explaining the result

8. Drawing the conclusion from the result.

\section{FINDINGS AND DISCUSSION}

In this section, the researchers present the findings of the analysis of types of grammatical errors found in essays written by 20 students in the third semester of Purworejo Muhammadiyah University, Indonesia. The analysis of types of errors is based on Keshavarz's theory because it describes how errors take place in a sentence, and it is also a new theory of error analysis. There are omission, addition, substitution, and permutation. Here is the table of the recapitulation of types of grammatical errors found in students' essays.

Table 1:

The Recapitulation of Types of Grammatical Errors

Found in Students' Essays Written by the Third-Semester Students of Purworejo Muhammadiyah University, Indonesia.

\begin{tabular}{cccc}
\hline No. & Types of Errors & Total & Percentage (\%) \\
\hline 1. & Omission & 47 & 34.06 \\
2. & Addition & 10 & 7.25 \\
3. & Substitution & 80 & 57.97 \\
4. & Permutation & 1 & 0.72 \\
& Total & 138 & 100 \\
\hline
\end{tabular}

The table shows that the third-semester students of Purworejo Muhammadiyah University, Indonesia. They still made grammatical errors in writing their essays. The total number of grammatical errors committed by them is 138. The total number for each error type is 47 (omission), 10 (addition), 80 (substitution), and 1 (permutation). The analysis result shows 
that the percentage for each error type is $34.06 \%$ (omission), $7.25 \%$ (addition), $57.97 \%$ (substitution), and $0.72 \%$ (permutation). Based on the research result, it can be concluded that the most dominant error found in students' essays is substitution. The percentage of error can prove it, that is, $57.97 \%$.

\section{Types of Grammatical Errors Found in Students' Essays Written by the Third-Semester Students of Purworejo Muhammadiyah University, Indonesia.}

This section deals with discussing findings of types of grammatical errors found in students' essays written by the third-semester students of a Purworejo Muhammadiyah University, Indonesia. In this section, the researchers discuss types of grammatical errors based on Keshavarz's theory. According to Keshavarz (2012), there are four types of errors: omission, addition, substitution, and permutation.

a. Omission

Here are examples of omission errors.

1) The omission of an inflection $-s$ to show the plurality of a noun. "A soft drink has many bad effect for our life." (R10)

The sentence written by the student is incorrect because there is no inflection $-s$ to show the plurality of a noun. The word many in the sentence shows that the noun is plural; however, there is no inflection $-s$ to the noun effect. The correct form of the noun is effects. Therefore, the correct sentence is, "A soft drink has many bad effects for our life."

2) The omission of an auxiliary verb in the form of be in a passive voice "It ${ }^{\wedge}$ also caused by high content of artificial sweeteners." (R3)

The sentence written by the student is not correct. It belongs to the omission of an auxiliary verb in the form of be in a passive voice. Here, the subject is it, and it is singular. In the present simple, the appropriate auxiliary verb for a singular subject is $i$ s. Therefore, the correct sentence is, "It is also caused by high content of artificial sweeteners."

3) The omission of an article "^ Most popular drink is soft drink." (R1)

The sentence does not have an article. It should be added by the article the in front of the phrase most popular. Thus, the correct sentence is, "The most popular drink is soft drink."

4) The omission of a verb be in an affirmative nominal sentence.

"Mineral water ^ good for health." (R9)

The sentence written by the student is incorrect because there is an omission of a verb be in an affirmative nominal sentence. The subject in the sentence above is Mineral water, and it is singular, so the appropriate verb be is $i$. Thus, the correct sentence is, "Mineral water is good for health." 
5) The omission of an inflection $-s$ to the verb in the present simple. "Soda contain carbonic acid." (R1)

The sentence written by the student is not correct because there is an omission of an inflection $-s$ to the verb in the present simple. The subject in the sentence is Soda, and it is singular. The verb contain should then be added with an inflection $-s$ because the tense is the present simple. Therefore, the correct sentence is, "Soda contains carbonic acid."

6) The omission of an object in a sentence "Obesity can happen if we consume ${ }^{\wedge}$ excessively." (R2)

The sentence written by the student is not correct because there is no object in a subordinate clause. In the subordinate clause above, the subject is we, the main verb is consume, and we can add an object soft drinks. Therefore, the appropriate sentence is, "Obesity can happen if we consume soft drinks excessively."

7) The omission of an inflection -ing to show gerund "The second effect is increase the risk of diabetes." (R11)

The sentence written by the student is not correct because there is no inflection -ing to the word increase to show that it is a gerund functioning as an object. The word increase should be changed into increasing. Therefore, the correct sentence is, "The second effect is increasing the risk of diabetes."

8) The omission of a subject in a noun clause

"The first effect of a soft drink is that ^ can cause dehydration." (R6)

The sentence is not correct because there is no subject in a noun clause. The noun clause is indicated by the subordinate conjunction that. We can add a subject it because it can refer to a soft drink. Therefore, the appropriate sentence is, "The first effect of a soft drink is that it can cause debydration."

9) The omission of be in a passive voice with modal auxiliary "Tooth decay can ${ }^{\wedge}$ caused by the artificial sweeteners contained in the soft drink." (R10)

The sentence written by the student is incorrect because there is an omission of be in a passive voice. In the passive voice above, there is a modal auxiliary can. Then, after the modal auxiliary, it should be added by the word be. Thus, the appropriate sentence is, "Tooth decay can be caused by the artificial sweeteners contained in the soft drink."

b. Addition

Here are examples of addition errors.

1) The addition of the preposition

"Don't often to drink soft drinks." (R12)

The sentence above is incorrect because there is the addition of preposition to in an imperative sentence. The infinitive verb drink should directly follow the adverb of frequency often, and the 
preposition to must be deleted. Therefore, the correct sentence is, "Do not often drink soft drinks."

2) The addition of an auxiliary verb is before the modal auxiliary

"The conclusion is that the soft drink is should not be consumed excessively." (R5)

The sentence is incorrect because there is the addition of an auxiliary verb is before the modal auxiliary should. It means that there are two auxiliaries in a noun clause. The auxiliary verb is must be omitted. Thus, the correct sentence is, "The conclusion is that the soft drink should not be consumed excessively."

3) The addition of a verb be in an affirmative sentence with a modal auxiliary. "Soft drinks can be reduce the functions of kidney." (R13)

The sentence is incorrect because there is the addition of a verb be to the affirmative sentence with a modal auxiliary can. The affirmative sentence containing a modal auxiliary only uses a modal auxiliary and an infinitive verb. The word can must be followed by the infinitive verb reduce. The verb be must be omitted. Therefore, the correct sentence is, "Soft drinks can reduce the functions of kidney."

c. Substitution

Here are examples of substitution errors.

1) The substitution of an incorrect spelling instead of a correct spelling "Soft drinks also chage the color of the teeth." (R1)

In the sentence above, there is a misspelling word chage instead of change. Thus, the correct sentence is, "Soft drinks also change the color of the teeth."

2) The substitution of a singular verb instead of a plural verb

"Soft drinks increases the diabetes risk." (R12)

The subject of the sentence is Soft drinks, and it is plural. However, the sentence uses the singular verb increases. The correct one is increase. Therefore, the correct sentence is, "Soft drinks increase the diabetes risk."

3) The substitution of a plural verb instead of a singular verb "A soft drink have high acidity level." (R1)

Here, there is a substitution of a plural verb instead of a singular verb. The subject in the sentence is $A$ soft drink, and it is singular, so the correct verb is in the singular form. The singular form of the verb have is has. Therefore, the correct sentence is, "A soft drinke has high acidity level."

4) The substitution of the incorrect pronoun instead of the correct pronoun

"Soft drinks have many negative effects. The are bad for us." (R2)

In the sentence above, there is a substitution of the pronoun the instead of they. The subject in the first sentence is Soft drinks, and it is plural, so the appropriate pronoun referring to soft drinks are they. 
Therefore, the correct sentence is, "Soft drinks have many negative effects. They are bad for us."

5) The substitution of a plural noun instead of a singular noun "The first effects is obesity." (R3)

The verb is indicates that the subject is singular. However, there is an inflection $-s$ to the word effect. It should be in a singular form. The correct one is effect. Thus, the well-structured sentence is, "The first effect is obesity."

6) The substitution of an adjective instead of a noun

"Many people don't know bad effects of soft drinks, especially for bealtby." (R1)

The preposition for must be followed by the noun. The word bealthy is an adjective. The appropriate noun is health. Thus, the correct sentence is, "Many people don't know bad effects of soft drinks, especially for bealth."

7) The substitution of a noun instead of a verb "If you consumption soft drinks, you can damage your teeth." (R3)

The first type of conditional sentence uses the present simple in the subordinate clause. The subject you must be followed by the verb consume because the word consumption is a noun. Therefore, the correct sentence is, "If you consume soft drinks, you can damage your teeth."

8) The substitution of a past verb instead of an infinitive verb "Besides being able to caused obesity, soft drinks can also cause diabetes." (R15)

After the preposition to, we should add an infinitive verb. The verb caused is a past verb. The infinitive form is cause. Therefore, the correct sentence is, "Besides being able to cause obesity, soft drinks can also cause diabetes."

9) The substitution of a singular present verb instead of an infinitive verb "Drinking soft drinks can causes obesity." (R15)

The affirmative sentence with a modal auxiliary can uses an infinitive verb. However, there is an inflection $-s$ to the main verb cause in the sentence. The correct verb is cause, and it must be placed after the modal auxiliary can. Therefore, the correct sentence is, "Drinking soft drinks can cause obesity."

10) The substitution of a progressive verb instead of an infinitive verb and the substitution of the incorrect pronoun instead of the correct pronoun "If you often drinking soft drinks, it can cause bad effects on our health." (R4)

The sentence above is the first type of conditional sentence. In the subordinate clause, after the adverb of frequency often, it should be followed by the present verb. The subject in the first clause is you, so the correct verb is drink. Then, viewed from the subject in the first 
clause, the correct pronoun before the noun health is your. Therefore, the correct sentence is, "Ifyou often drink soft drinks, it can cause bad effects on your bealth.

\section{d. Permutation}

Here is the example of permutation error.

The permutation of the position of too much

"If you too much drink soft drinks, it will not be good for health." (R16)

In the sentence, the phrase too much is positioned before the verb drink. The phrase too much must be placed after the phrase soft drinks. Therefore, the well-structured sentence is, "If you drink soft drinks too much, it will not be good for health."

If we compare to the first previous research, this research found errors of omission, addition, misformation, and misordering. However, it has different term, Keshavarz uses the term 'substitution' instead of 'misformation', and he uses the term 'permutation' instead of 'misordering'. This research found addition errors, while the first previous research did not. The first previous research only analyzed errors in using linking verbs and to be auxiliary, while this research analyzes all grammatical errors. Compared to the second previous research, in this research, the researchers only found the error of using preposition to in an imperative sentence, while the second previous research found many preposition errors. Compared to the last previous research, the researchers did not find substitution errors in using English articles, while the last previous research found many English articles substitution errors.

\section{CONCLUSION}

It is crucial for the lecturer to do the error analysis to detect students' errors in their essays. Based on the research result, the total of grammatical errors committed by 20 third-semester students of Purworejo Muhammadiyah University, Indonesia, is 138. The total number of errors for each error type is 47 (omission), 10 (addition), 80 (substitution), and 1 (permutation). The analysis result shows that the percentage for each error type is $34.06 \%$ (omission), $7.25 \%$ (addition), $57.97 \%$ (substitution), and $0.72 \%$ (permutation). The researchers draw the conclusion that the most dominant error is substitution. The percentage of error can prove it, that is, $57.97 \%$.

There are some implications of error analysis in English language teaching in universities in Indonesia. First, the lecturer can give enrichment based on students' errors. The lecturer can repeat and emphasize the materials related to students' errors, explain the materials clearly, and develop the exercises to enhance students' understanding and knowledge. Second, the lecturer can understand students' grammar competence. Error analysis informs the lecturer about what learners know and how they apply the rules 
of the target language. The researchers found that some students always attached the inflection $-s$ to the plural subject using to be are and to the singular subject using to be is in the present simple in their essays. On the contrary, related to the use of the inflection $-s$ to the subject, they can only use it to the plural subject using to be are. Third, the lecturer can provide the corrective feedback to students' errors. Corrective feedback is very crucial in English language teaching because it can improve students' understanding of the materials. Here, the lecturer can provide the correction for students' errors to improve their grammar understanding and writing quality. Fourth, the lecturer can modify target language (TL) learning items in classrooms and textbooks. The lecturer can emphasize the materials containing students' errors and give more explanations that allow students to correct their errors. The teacher can develop the exercises in textbooks by giving more exercises emphasizing students' errors. For example, most of the students made errors in the passive voice, so that the lecturer can develop some exercises about passive voice in textbooks. Fifth, the lecturer can understand the way students apply the target language rules. Error analysis gives evidence about students' knowledge about the target language and how they use the knowledge to produce sentences. Here, the systematic deviations can be found; for example, when students learn the passive voice, they must use the inflection $-e d$ to the main verb. However, they also attach the inflection $-e d$ to the main verb in other tenses. Sixth, the lecturer can use the effective teaching method or learning media. For example, when most of the students omit the verb be in writing a nominal sentence in the present simple, the lecturer can apply the deductive method by giving a detailed explanation about how to write a nominal sentence in the present simple or apply the inductive method by giving some sentences errors and asking students to correct them. The lecturer can also use audio-visual media to improve students' grammar knowledge and writing performance.

\section{REFERENCES}

Afdaleni. (2018). Students' Interest Level in Learning English Grammar. Asian EFL Journal, 20(4), 61-65.

Anjayani, P., \& Suprapto. (2016). Error Analysis on the Use of Prepositions in Students' Writing (A Case Study of the Eleventh Grade Students of SMA Negeri 9 Semarang in the Academic Year of 2014/2015). ELT Forum:Journal of English Language Teaching, 5(2), 1-6.

Batu, P. N. F. L., Barasa, L. P. L., \& Sitepu, V. T. (2018). Grammatical Errors in Students Speaking English: An Error Analysis on Indonesian Maritime Students. Asian EFL Journal, 20(7), 88-93.

Calanoga, M. C. M. (2019). Mechanics and Grammar Error Analysis in Students' Write-Ups: Basis for Incidental Teaching in the Classroom. Asian EFL Journal, 23(3.3), 104-125. 
Calanoga, M. C. M., \& Arellano - Tamayo, R. (2019). Error Analysis of Student Interns' Reflective Journals: Basis for a Grammar Remediation Class. Asian EFL Journal, 23(3.2), 220-236.

Cam, L., \& Tran, T. M. T. (2017). An Evaluation of using Games in Teaching English Grammar for First Year English-Majored Students at Dong Nai Technology University. International Journal of Learning, Teaching and Educational Research, 16(7), 55-71.

Catabay, M. Q. (2019). Error Analysis in Sentence Writing of Second Language Learners. Asian EFL Journal, 24(4.2), 64-79.

Fontiveros - Malana, M., \& Calanoga, M. C. M. (2019). Students' Strategies and Competence in Writing Compositions. Asian EFL Journal, 22(1), $178-200$.

Hamilton, C. E. (2015). The Contribution of Systemic Functional Grammar to the Error Analysis Framework. TESOL International Journal, 10(1). http://www.tesol-international-journal.com

Heigham, J., \& Croker, R. A. (2009). Qualitative Research in Applied Linguistics: A Practical Introduction (First). Palgrave Macmillan.

Heydari, P., \& Bagheri, M. S. (2012). Error Analysis: Sources of L2 Learners' Errors. Theory and Practice in Language Studies, 2(8), 1583-1589. https://doi.org/10.4304/tpls.2.8.1583-1589

Ilyas, Moh. (2019). Developing Descriptive Writing through Process Approach to Indonesian Primary School Students. Asian EFL Journal, 26(6.2), 205-224.

Keshavarz, M. H. (2012). Contrastive Analysis and Error Analysis. Rahnama Press.

Khansir, A. A. (2012). Error Analysis and Second Language Acquisition. Theory and Practice in Language Studies, 2(5), 1027-1032. https://doi.org/10.4304/tpls.2.5.1027-1032

Kusumawardhani, P. (2017). The Analysis of Errors of Omission in English Narrative Composition Made by EFL Students. Journal of English Language and Education, 3(2), 84-96.

Manuel, J. B. (2019). Sentence Errors Committed in the Paragraph Writing among Senior High School Students. Asian EFL Journal, 23(3.4), 334351.

Marashi, H. (2014). Using Inductive and Deductive Consciousness Raising Tasks to Improve Field-Dependent and Field-Independent EFL Learners' Grammar. The Iranian EFL Journal, 10(3), 60-74.

Mendoza, P. J. L. (2016). Analysis of in-class Writing Errors of College Freshmen Students. Asian EFL Journal, 17, 2-26.

Oktaviana, F. (2018). Comparison of Translation Result from GoogleTranslator and Bing-Translator (Error Analysis of Translation Result from Indonesian Text into English Text). The Asian ESP Journal, 14(5), 17-29.

Oshima, A., \& Hogue, A. (1998). Writing Academic English (Third). Addison Wesley Longman. 
Pamittan, F. A. (2019). Investigating ESL Freshmen Students' Writing Proficiency. Asian EFL Journal, 22(1), 226-240.

Patoc, L. A. F., \& Lasaten, R. C. S. (2019). Grammatical Errors Reflected in the Narrative Compositions of Grade 7 Students: Bases in the Development of a Learning Support Material in English Grammar. Asian EFL Journal, 21(2.4), 57-87.

Qamariah, H., \& Wahyuni, S. (2020). An Analysis Of Students' Grammatical Errors In Writing English Text In The Second Grade Students Of Smk-Smti Banda Aceh. Getsempena English Education Journal, 7(1), 5871.

R, M., Yusri, \& Jufri. (2018). The Development of Grammar Teaching Material Using Error and Contrastive Analysis (A Linguistic Approach in Foreign Language Teaching). TESOL International Journal, 13(3), 2-13.

Ramos, I. D. D. (2015). Error, Register, Grammatical-Rhetorical, and Genre Analyses on Nursing Students' Case Studies and Thesis Proposals. The Asian ESP Journal, 11(2), 62-97.

Ratnah. (2018). Improving Writing Skills by Using Authentic Materials in Indonesian Vocational School. Asian EFL Journal, 20(7), 124-129.

Rusyaidi, A. M. (2018). The Effective Use of Error Categorization Matrix in Improving Students Writing Skill. Asian EFL Journal, 20(4), 116-121.

Shariq, M. (2020). Difficulties Facing Saudi EFL Learners with Translation: Contrastive and Error Analysis. Asian EFL Journal, 27(3.3), 13-27.

Sidupa, C., \& Rahyono. (2019). Lexical Quality of English Language Writing of Undergraduate Students in Indonesia. Asian EFL Journal, 26(6.2), $5-21$.

Siew Eng, L., Luyue, C., \& Kuan Lim, C. (2020). A Comparison of the English Grammatical Errors of Chinese Undergraduates from China and Malaysia. International Journal of Instruction, 13(1). www.e-iji.net

Simbolon, M. (2015). An Analysis of Grammatical Errors on Speaking Activities. Journal on English as a Foreign Language, 5(2), 71-86.

Sioco, E. C., \& Vera, Dr. P. V. D. (2018). Grammatical Competence of Junior High School Students. TESOL International Journal, 13(2), 82-94.

Susanto, Soengkono, N., \& Assalma, O. H. (2019). The Effect of Peer Feedback on Students' Writing Anxiety and Students' Writing Ability. Asian EFL Journal, 26(6.2), 63-82.

Swasti, S. B. (2016). An Error Analysis on The Use of English Articles in Students' Written Descriptive Texts a Case of Class X MIA 1 of SMA N 1 Binangun, Cilacap in the Academic Year 2014/2015. ELT Forum:Journal of English Language Teaching, 5(1), 1-10. 
Talosa, A. D., \& Maguddayao, R. N. (2018). Evaluation of Second Language Learners' Syntactic Errors in ESL Writing. TESOL International Journal, 13(4), 172-181.

Zheng, C., \& Park, T. J. (2013). Zheng, C., \& Park, T. J. (2013). An analysis of errors in English writing made by Chinese and Korean University Students. Theory and Practice in Language Studies, 3(8), 1342-1351. Theory and Practice in Language Studies, 3(8), 1342-1351. 